\title{
A HISTORICAL NOTE ON INFLUENZA IN ETHIOPIA
}

\author{
by
}

\section{RICHARD PANKHURST*}

The Distinguished German medical historian Dr. K. F. Schaller recently remarked that "because of its geographical position" Ethiopia "in former times ... remained mostly unaffected by the world-wide influenza epidemics."1 This statement would seem to require revision, for though documentation on Ethiopia's medical history is fragmentary, and many of the epidemics which appeared in the past ${ }^{2}$ cannot be identified, there is evidence to suggest that diseases of the influenza variety have been known for at least a quarter of a millennium, and that at least some epidemics coincided with international outbreaks.

Towards the end of the seventeenth century the German scholar, Job Ludolf, who wrote in part on the basis of information provided by his Ethiopian friend Abba Gregorios, reported that on the outbreak of a pestilence the people often retired with their cattle to the mountains, "putting all their Security in flying from the Contagion."3 The German included in his Amharic-Latin dictionary of 1698 the local names of two diseases, namely gunfan or "Catarrhus" and gunfanam or "Catarrhis obnoxious". ${ }^{4}$ The former probably referred then, as now ${ }^{5}$ to both the common cold and influenza, the latter to a more acute complaint, possibly also influenza. The term gunfan, though used for a cold, seems also to have served for more deadly epidemics, presumably of influenza, which are recorded as having struck the country at least twice in the early eighteenth century.

The first of these epidemics raged around 1706, and is mentioned in a royal chronicle of Emperor Iyasu I which states that there was an outbreak of gunfan as a result of

*R. Pankhurst, B.Sc., Ph.D., Institute of Ethiopian Studies, Addis Ababa University, P.O. Box 1176, Addis Ababa, Ethiopia; and School of Oriental and African Studies, University of London.

${ }^{1}$ K. F. Schaller and W. Kuls, Athi-pien-Ethiopia, Berlin and Heidelberg, Springer Verlag, 1972, p. 119.

2 R. Pankhurst, 'The history and traditional treatment of smallpox in Ethiopia', Med. Hist., 1965, 9: 343-355; idem, An introduction to the economic history of Ethiopia, London, Lalibela House, 1961, 238-241; idem, 'The history of cholera in Ethiopia', Med. Hist., 1968, 12: 262-269; idem, 'The history of famine and pestilence in Ethiopia prior to the founding of Gondar', J. Ethiopian Studies, 1972, 10: No. 2: 37-64; idem, 'Some notes for the history of typhus in Ethiopia', Med. Hist., 1976, 20: 384-393.

- J. Ludolf, A new history of Ethiopia, London, Samuel Smith, 1682, p. 377.

- J. Ludolf, Lexicon Amharico-Latinum, Frankfurt, Martinus Jacquetus, 1698, col. 89.

- W. Leslau, English-Amharic context dictionary, Wiesbaden, Otto Harrassowitz, 1973, p. 209. 


\section{Short Articles}

which the emperor's son and heir Takla Haymanot, following the practice earlier spoken of by Ludolf, had been obliged to leave his residence, while "many people fell ill" of gunfan, and an unspecified number of men and women died. ${ }^{6}$

The second known outbreak of the eighteenth century occurred in 1747, and was again deadly. The chronicle of Emperor Iyasu II states that "many illnesses raged in the town" of Gondar "and in all the country; the dead were so numerous that people to bury them could not be found; many people died suddenly; there was no one who did not fall ill of this gunfan."”

The chronicles of this period mention several other epidemics, but usually fail either to indicate the name of the disease or to give any account of its symptoms, and therefore leave us in uncertainty as to what extent they could have been influenza.

\section{II}

In the nineteenth century Ethiopia was visited by numerous foreign travellers, several of them physicians, whose writings tend from the medical point of view to be more precise than those of the chroniclers of yore. In the early years of the century, however, visits of doctors were few and far between. It is particularly unfortunate that there were no medical observers in the country in 1803,1833, 1837 and 1847, the years which witnessed the principal early nineteenth-century influenza epidemics in other parts of the world. ${ }^{8}$ The Ethiopian chronicles for this period are moreover particularly defective. There is therefore no means of assessing how far the international epidemics of this period may have impinged on the country.

Despite such dearth of critical documentation, there are several references in this period to the outbreak of unidentified fevers," and "pernicious miasmas"10 which may or may not have been influenza, as well as to common colds and sore throats (which were traditionally treated with honey). ${ }^{11}$ Mention is likewise made of a "cerebral fever" which carried off a "large number" of the inhabitants of Mahdara Maryam in Begamder towards the end of 1835 or beginning of 1836, obliging Empress Manan to flee the town, and of a "terrible" epidemic which "decimated" the inhabitants of the port of Massawa in April 1836.12 We cannot, however, at this stage establish the identity of these diseases.

Our first strictly medical account of an Ethiopian influenza epidemic is for the year 1839, and was written by a French physician, Dr. A. Petit, a member of a scientific mission despatched by King Louis Philippe of France. Petit, who witnessed this

- R. Basset, Etudes sur l'histoire d'Ethiopie, Paris, Imprimerie nationale, 1882, pp. 58, 169; F. Béguinot, La cronaca abbreviata d'Abissinia, Rome, Tipografia della Casa Editrice Italiana, 1901, p. 84; but see also J. Bruce, Travels to discover the source of the Nile, Edinburgh, J. Ruthven, 1790, vol. 2, p. 515.

' I. Guidi, Annales regum Iyasu II et Iyo'as, Paris, Corpus Scriptorum Christianorum Orientalium, 1910,1912 , text, p. 139 , translation, p. 150.

- The Times, 12 November 1918.

- E. Combes and M. Tamisier, Voyage en Abyssinie, Paris, Louis Desessart, 1838, vol. 1, p. 278; vol. 3, p. 312; S. Gobat, Journal of a three years' residence in Abyssinia, London, Seeley, Burnside, \& Seeley, 1847, pp. 191-192, 268-269.

${ }^{10}$ P. Ferret and J. G. Galinier, Voyage en Abyssinie, Paris, Paulin, 1847, vol. 2, p. 29.

11 N. Pearce, The life and adventures of Nathaniel Pearce, London, Henry Colburn and Richard Bentley, 1831, vol. 1, pp. 297, 303.

12 Combes and Tamisier, op. cit., note 9 above, vol. 4, pp. 215-224. 


\section{Short Articles}

outbreak in the town of Adwa, notes that it was far less serious than others remembered by the inhabitants who said these attacks had been "more grave, and could even become fatal." This statement, it may postulated, perhaps referred to the local experience of the afore-mentioned international outbreaks of 1833 and 1837.

Turning to the attack of 1839 Petit tells us that "at the beginning and the end of the rains, that is to say in July and September, Adwa was the theatre of an epidemic illness which seemed to be the same by its nature, even though it was not always identical in its manifestations." Discussing the first phase of the epidemic he relates that by the middle of July, "the greater part of the inhabitants" of Adwa had fallen victim to the disease. The malady began with a feeling of discomfort, lassitude in the limbs, weakness and a kind of inability to move. Soon afterwards there developed an acute inflammation of the pituitary membrane of the nose with considerable secretion in the eyes and nasal chambers, the latter being also the seat of strong tingling, while the front sinus was characterised by a feeling of discomfort and constriction, the inflammation often extending to the laryngo-pharyngeal mucous membrane thereby producing angina. In many cases the irritation later descended into the bronchus, and gave way to a true catarrh with coughing and mucous expectoration. At the same time, or more often several days later, there developed a very intense cephalagia, or head-ache, while the general weakness became more acute, and the patient became victim of "an inexpressible discomfort". The pain seemed to be situated on the exterior of the head, almost in the skin of the hair, because the application of strong pressure with the hands reduced or even removed it, as sometimes the case with nervous complaints. The general discomfort usually extended as far as the ears and teeth which became extremely sensitive. The pulse was usually slow, full and vibrant, though sometimes almost normal; this difference in the circulation, according to Petit, seemed to be related to the state of the skin, hot and dry in the first case, and moist in the second. The tongue, yellowish in the middle, was large and humid, and the belly, sluggish; in certain cases there was a desire to vomit, though the movement of the bowels was almost always normal, there was finally a greater or lesser feeling of discomfort in all the limbs, but particularly in the legs and shoulders.

The second outbreak of 1839 occurred two months later, in September, when the disease seemed to have been modified: the neuralgic pains so characteristic of the first attack showed themselves only in exceptional cases, the cephalalgia being normally limited to one side of the head or face.

Discussing this dual epidemic of 1839, Petit declared that the disease, as manifested in Ethiopia, responded to emetics with ipecacuanha and saline purgatives, though sometimes it was considered necessary to have recourse to bleeding. ${ }^{13}$

Ethiopian influenza, in part perhaps because it displayed little difference from the disease in other countries, and in part because of its normally mild character, received scant attention from the foreign travellers of the second half of the century. There is, however, evidence of an outbreak in 1889-90 which came in the wake of the great Ethiopian famine of that time ${ }^{14}$ when the starving population also fell easy prey to

18 T. Lefebvre, Voyage en Abyssinie, Paris, A. Bertrand, 1848, vol. 2, pp. 356-358.

${ }^{14} \mathrm{R}$. Pankhurst, 'The great Ethiopian famine of 1888-1892; a new assessment', J. Hist. Med., 1966, 21 : 95-124, 271-294. 


\section{Short Articles}

smallpox, cholera and typhus. This influenza outbreak in all probability formed part of the current world influenza epidemic. A French physician Dr. R. Wurtz, who studied health conditions in Ethiopia a few years later, claims that at the end of 1889 there was a "murderous epidemic" of influenza which "decimated the population", and quotes Emperor Menilek's Swiss adviser Alfred Ilg as stating that there were more than 20,000 sick men in the army, a large number of whom died with symptoms resembling those of severe influenza. ${ }^{15}$

Influenza, as well as the common cold, continued to be referred to in Amharic throughout this time as gunfan, gumfan or genfan, as recorded in the dictionaries of the German missionary C. W. Isenberg, who equated the term with "a cold, a cough, catarrh, rheum", ${ }^{16}$ and of the French traveller d'Abbadie, ${ }^{17}$ though lexicographers and linguists of the early twentieth century indicate that the spelling gunfan was by then normal. ${ }^{18}$ A common saying of this time was: "He who with gunfan catches a dog, a child or a goat, cannot remain hidden." ${ }^{19}$ That the term gunfan was widely used for influenza is expressly noted by Isenberg who lists the disease in his dictionary with the translation yagunfan aynat, or "gunfan-type," $1841 .{ }^{20}$

III

The frequency of influenza epidemics in early twentieth-century Addis Ababa is recorded by the notable Georgian physician, Dr. P. Mérabashvilli, better known as Dr Mérab, who arrived in the capital in 1908 and provides us with a revealing glimpse into the medical situation of the town from which, he says, the disease was no stranger.

Mérab, who founded the city's first and for a time sole pharmacy, recalls in his informative study, Médecins et médecine en Ethiopie, that Addis Ababa had suffered, since his arrival only half a decade or so earlier, from several influenza epidemics. Most of the cases he had seen were of the gastro-intestinal and to a lesser extent pulmonary forms, while the nervous variety was exceptional. There were also slight cases of the disease, often referred to as mech. ${ }^{21}$ Cases were often "aggravated, thanks to the negligence of the natives who do not throw themselves on the doctor until they have exhausted all the means."

As for popular attitudes to the disease as revealed by his clients, Mérab states that it was often "attributed to the influence of the sun, as with us to that of the cold," though some people thought it was caused by the "evil eye", or, as others said, by a dead cat thrown by some evil disposed person on one's bed or in one's room or courtyard.

${ }^{16}$ R. Wurtz, 'Hygiéne publique et privée en Abyssinie', Sem. Med., 1898, 8: 492.

${ }^{16} \mathrm{C}$. W. Isenberg, Dictionary of the Amharic language, London, Church Missionary Society, 1841, vol. 1, p. 176; vol. 2, pp. 44, 112.

17 A. D’Abbadie, Dictionnaire de la langue amarinna. Paris, F. Vieweg, 1881, col. 886.

18 I. Guidi, Vocabolario amarico-italiano, Rome, Casa Editrice Italiana, 1901, cols. 765; G. J. Afevork, Grammatica della lingua amarica, Rome, Tipografia della R. Accademia dei Lincei, 1905, p. 51 ; idem, Guide du voyageur en Abyssinie, Rome, Imprimerie C. de Luigi, 1908, p. 25; J. Baeteman, Dictionnaire amarigna-francais, Dire-Daoua, Imprimerie Saint Lazaire, 1929, col. 1079.

10 Guidi, op. cit., note 18 above, cols. 765-766; Baeteman, op. cit., note 18 above, col. 1079.

${ }^{20}$ Isenberg, op. cit., note 16 above, vol. 2, p. 112. See also D. Brielli, V. Calo and A. Bevilacqua, Note di patologia etiopica, Rome, Tipografia nazionale di G. Bertero, 1913, p. 86.

2 Guidi, op. cit., note 18 above, cols. 83-84. 


\section{Short Articles}

Popular cures, according to the Georgian, included the roots of téna Adam (ruta montana) mixed with barbaré, or red pepper, marshmallow leaves, and other things, all boiled together with taj, or honey wine. Another remedy was a concoction made from the root of a plant called baglat [?] or sheep's tail, a kind of convolulaceae which possessed cathartic properties. This specific was drunk and rubbed on the body. There was also a plant the name of which was kept a rigid secret. Its juice was placed in the ears and nose, and was supposed to produce an almost instant cure. Use was likewise made of the bryony which was boiled, the patient being exposed to the resultant vapours, after which he was not to leave his house on the morrow until he had changed his shamma, or toga, in default of which it was believed that the illness would return. Finally, Mérab mentions some unspecified emetic which was used in cases of gastritic influenza. ${ }^{22}$

Ethiopia shortly afterwards suffered from a visitation of "Spanish 'flu" which spread throughout most parts of the world in 1918 towards the end or immediately after World War I. ${ }^{23}$ This outbreak, which is far better documented than any previous epidemic, and has been examined elsewhere by the present writer, ${ }^{24}$ appeared, as in other countries, in two waves, first in mild form in the summer, and then, much more virulently, in the autumn. ${ }^{25}$ Mortality in Ethiopia, as in other parts of the East, notably India where 15,000 persons died in Bombay, ${ }^{28}$ was extremely high. It is estimated that 10,000 persons perished in Addis Ababa alone, ${ }^{27}$ the death rate being accentuated by the acute shortage of doctors, the majority of whom died of the virus. The epidemic, because of its heavy mortality in the Ethiopian month of Hedar, i.e. October-November, became popularly known as Hedar Bašita ("disease of Hedar") ${ }^{28}$ but, on account of French contacts in this period, was also spoken of as grip, from the French "grippe", ${ }^{29}$ though the indigenous word wararseñ also gained favour, apparently in this period. ${ }^{30}$ Post-World War II contacts with the Englishspeaking world have, however, more recently popularized the word enfluwénza which is listed in the American linguist Wolf Leslau's context dictionary of $1973 .{ }^{31}$

The evidence of the Hedar basita of 1918, and the more fragmentary data on outbreaks of the previous two centuries, indicates that influenza, though normally far less serious that the three "killers", smallpox, cholera and typhus, deserves a place in the history of Ethiopian epidemics, and was by no means unaffected by attacks in other parts of the world.

22 P. Mérab, Médecins et médecine en Ethiopie, Paris, Vigot Fréres, 1914, pp. 104-105.

23 C. F. Rey, Unconquered Abyssinia, London, Seeley, Service, 1923, p. 48.

${ }^{24}$ R. Pankhurst, 'The Hedar basita of 1918', J. Ethiopian Studies, 1975, 13: No. 2, 103-131.

${ }^{25}$ The Times, 27 June, 8, 22 July and 18 September 1918. See also F. M. Burnet and E. Clark, Influenza: a survey of the last fifty years, Melbourne, Macmillan, 1942, p. 69ff; Great Britain, Ministry of Health, Report on the pandemic of influenza, 1918-19, London, H.M.S.O., 1920, passim.

28 The Times, 17 and 18 September and 2 December 1918.

${ }^{27}$ Hayla Sellasé, Heywatena Yaltyopya erméja, Addis Ababa, Berhanena Salam Matamya Bét, 1964 Ethiopian calendar, p. 39.

${ }^{28}$ Baeteman, op. cit., note 18 above, col. 428; I. Guidi, Supplemento al vocabolorio amaricoitaliano, Rome, Istituto per l'Oriente, 1940, col. 6.

${ }^{20}$ Heruy Walda Sellasé, Yaheywat tarik, Addis Ababa, Ya Ityopya Mangast Alga Arash BaLe'ul Ras Tafari Matamya Bét, 1915 Ethiopian calendar, pp. 75-76.

${ }^{20}$ Baeteman, op. cit., note 18 above, col. 750; Schaller and Kuls, op. cit., note 1 above, p. 119.

${ }^{21}$ Leslau, op. cit., note 5 above, p. 639. 


\section{Short Articles}

SUMMARY

Contrary to the assertion that Ethiopia was too isolated to be affected by international influenza epidemics, there is evidence that the disease reached the country from abroad on a number of occasions. First mentioned in an Amharic-Latin dictionary of 1698, the earliest identifiable outbreaks of the illness were in 1706 and 1748, both of which resulted in high mortality. Later epidemics included an attack of the "Spanish 'flu" of 1918, locally called Hedar bašita, or "disease of Hedar," the name of the Ethiopian month (October-November) of the highest death rate.

The malady was traditionally attributed to the influence of the sun, or even to the "evil" eye, and was treated by various herbal medicines, while it was not uncommon during epidemics for persons to isolate themselves from suspected foci of infection. Influenza, though less serious than smallpox, cholera, and typhus, played a major role in Ethiopia's medical history, and was known both by indigenous names and, in recent periods of modernization, by foreign loanwords, i.e. grip from the French, and enfluwénza from the English. 